\title{
Human dominion and wild animal suffering
}

\author{
Dustin Crummett \\ Ludwig Maximilian University of Munich, Chair of Late Antique and Arabic Philosophy, Geschwister- \\ Scholl-Platz 1, Munich 80539, Germany \\ E-Mail: dustin.crummett@gmail.com
}

(Received 9 March 2021; revised 23 July 2021; accepted 25 July 2021)

\begin{abstract}
It may be possible, now or in the future, for humans to technologically intervene to reduce the amount of suffering experienced by wild animals. There is a debate about whether, if humans can do this, they should. Here, I consider the implications for this debate of the theological claim that humans have been granted dominion over the other animals. I argue that it's more plausible to interpret the dominion claim as granting humans (i) the responsibility to care for the wellbeing of individual animals than to interpret it as giving humans either (ii) the right to do whatever they want to other animals or (iii) the responsibility to care only for the well-being of aggregates of animals (such as whole species). I then show how this understanding of dominion undermines a range of arguments against intervening to reduce wild animal suffering. These arguments claim that humans do not stand in the right sort of relationship for intervention to be obligatory (or perhaps even permissible). But if we possess such dominion, we do stand in the right sort of relationship for it to be obligatory.
\end{abstract}

Keywords: wild animal suffering; animal ethics; Korsgaard; McMahan; predation

\section{Introduction}

Richard Dawkins $(1995,131)$ writes that the amount of wild animal suffering

is beyond all decent contemplation. During the minute it takes me to compose this sentence, thousands of animals are being eaten alive; others are running for their lives, whimpering with fear; others are being slowly devoured from within by rasping parasites; thousands of all kinds are dying of starvation, thirst and disease. It must be so. If there is ever a time of plenty, this very fact will automatically lead to an increase in population until the natural state of starvation and misery is restored.

Perhaps the significant majority of wild animals have mostly bad lives. Kyle Johanssen (2021, 1) notes:

only some wild animals (K-strategists) protect their genes by restricting reproduction to a small number of cared-for offspring. Many animals protect their genes by producing large numbers of uncared-for offspring. This evolutionary reproductive

(c) The Author(s), 2021. Published by Cambridge University Press. This is an Open Access article, distributed under the terms of the Creative Commons Attribution licence (http://creativecommons.org/licenses/by/4.0/), which permits unrestricted re-use, distribution and reproduction, provided the original article is properly cited. 
strategy, normally referred to as the r-strategy, is used by many lizards, amphibians, fish, and small mammals. Instead of restricting reproduction and providing intensive care, r-strategists produce a large quantity of offspring, the majority of whom die from disease, starvation, injury, exposure, or predation shortly after birth . . . In other words, your typical r-strategist infant crawls around uncomfortably for a short while, after which it dies either a quick and painful death, or a slow and painful death.

Since $r$-strategists have so many more offspring, most individual animals are members of r-strategist species (cf. Horta (2017), sec. 3). Exactly how bad things are might depend on how far sentience extends: for example, Dustin Crummett (2017) argues that if insects and other arthropods are sentient, the proportion of suffering to flourishing may be skewed even further in the direction of suffering.

Perhaps we can ameliorate this. For example, we've reduced rabies in some wild animal populations with oral vaccines administered through bait. This is because we don't want wild animals to give humans rabies. But it may also be possible to employ medical interventions like this on behalf of the animals themselves (Johanssen (2021), 6). Other potential interventions are more drastic. CRISPR allows gene editing. By strategically introducing individuals with edited genes into the wild and allowing them to breed, we can conduct 'gene drives', genetically re-engineering wild animal populations. There are already investigations into doing this to protect humans, for instance by sterilizing malaria-carrying mosquitos. But we might also do the same for parasites which afflict wild animals, such as the New World screwworm. These 'performers in a macabre parade' cause pain severe enough that 'infested people often require morphine before doctors can even examine the wound', so that 'every second of every day, hundreds of millions of animals suffer the excruciating agony of being eaten alive' (Esvelt (2019)). (The screwworm has already been eliminated from North America by introducing large numbers of sterilized individuals: this was done for economic reasons, to protect livestock herds. There have been no apparent ecological repercussions (ibid.).) Other uses of gene drives might be more drastic still. In the future, we might re-engineer r-strategists into K-strategists who have fewer offspring with better prospects. We might engineer predators into herbivores, or drive them extinct altogether, while keeping prey populations in check by reducing their birthrates. We might even remove the very capacity for suffering, replacing pain with various 'gradients of bliss' (Pearce (1995); McMahan (2016); Johanssen (2021)).

There are practical worries (cf. Johanssen (2021), ch. 4). But suppose these proposals really would work as planned. Some philosophers, such as Jeff McMahan (2016), Oscar Horta (2017), Kyle Johanssen (2021), and David Pearce (1995), argue that, if so, we should enact them. But others, such as Clare Palmer (2010), John Hadley (2006), Tom Regan (2004), Martha Nussbaum (2006), Christine Korsgaard (2018), and Sue Donaldson and Will Kymlicka (2011) argue that (at least for some of the more drastic interventions) we would have no obligation to enact them, or even an obligation not to enact them. Mostly this is because they don't think we stand in the right relations to wild animals for these interventions to be obligatory (or permissible).

In the next section, I discuss the biblical claim that humans possess dominion over non-human animals. I discuss various interpretations of this claim before settling on one. In the subsequent section, I argue that accepting this interpretation of human dominion undermines a variety of anti-interventionist arguments: if we possess this dominion, we do stand in the relations necessary for these interventions to be obligatory. I'm not saying the anti-interventionist arguments work absent a religious belief in human dominion. I think there are good independent objections to them, and I'll mention some 
along the way. I view the secular and theological considerations as mutually supporting: the dominion argument clears away any remaining uncertainty, while the secular objections show that the implications of the dominion account aren't independently implausible (and so aren't just counterexamples). I'll say more about this in the conclusion. Proponents of animal liberation often regard ideas of human dominion as superstitious relics responsible for indifference to the suffering inflicted upon animals by humans (cf. Singer (2002), ch. 5). If the argument I present is correct, something like the opposite is true for human dominion, properly understood: perhaps it actually mandates, not only that we end the suffering of animals at the hands of humans, but also that we end other forms of animal suffering, over and against secular arguments to the contrary.

\section{Dominion}

When God created humanity:

God said, Let us make man in our image, after our likeness: and let them have dominion over the fish of the sea, and over the fowl of the air, and over the cattle, and over all the earth, and over every creeping thing that creepeth upon the earth.

So God created man in his own image, in the image of God created he him; male and female created he them.

And God blessed them, and God said unto them, Be fruitful, and multiply, and replenish the earth, and subdue it: and have dominion over the fish of the sea, and over the fowl of the air, and over every living thing that moveth upon the earth.

And God said, Behold, I have given you every herb bearing seed, which is upon the face of all the earth, and every tree, in the which is the fruit of a tree yielding seed; to you it shall be for meat.

And to every beast of the earth, and to every fowl of the air, and to every thing that creepeth upon the earth, wherein there is life, I have given every green herb for meat: and it was so.

And God saw every thing that he had made, and, behold, it was very good. And the evening and the morning were the sixth day (Genesis 1:26-31, KJV).

I'll just assume this passage expresses some sort of theological truth, so that God really has given humans dominion over the animals. The not very nice interpretation of dominion regards humanity's authority over the animals as a form of what Elizabeth Anderson (2017, ch. 2) calls 'private government'. Under private government, governance is the leader's 'own business': leaders can act as they want, without obligations towards those over whom they hold authority. This is the authority claimed by absolute monarchs over their subjects, and by owners over inanimate property. If we held this authority over animals, we could exploit and dispose of them as we pleased.

Many have thought we had this type of authority (cf. Singer (2002), ch. 5). Anyway, humans often act like they do, whatever they think about the Bible. But the not very nice interpretation faces at least two problems. One is the hermeneutical problem of whether this is faithful to the Biblical text itself (cf. Hare (2010); Bauckham (2011), ch. 2; Clough (2012)). We mainly use animals by eating them. But both the humans and the animals are apparently vegetarians at this point in the story. God eventually gives Noah permission to eat animals (Genesis 9:1-6), but as Hare notes (2010, 123-124), the context of this permission - after the Fall and the Flood, and alongside the institution of capital punishment - suggests that this is a 'second-best' response to a non-ideal 
world. And eschatological pictures in Isaiah 11:6-9 and Hosea 2:18 suggest an eventual return to global vegetarianism. Isaiah writes:

The wolf also shall dwell with the lamb, and the leopard shall lie down with the kid; and the calf and the young lion and the fatling together; and a little child shall lead them.

And the cow and the bear shall feed; their young ones shall lie down together: and the lion shall eat straw like the ox.

And the sucking child shall play on the hole of the asp, and the weaned child shall put his hand on the cockatrice' den.

They shall not hurt nor destroy in all my holy mountain: for the earth shall be full of the knowledge of the Lord, as the waters cover the sea.

The question of the Noahide permission's implications for things like factory farming, or, more broadly, for people in modern societies who can easily return to the vegetarian ideal is never explicitly addressed, for obvious reasons. Anyway, dominion clearly isn't a licence to treat animals however we want, or the Noahide permission wouldn't have been needed.

Further, while hermeneutical questions are difficult, the not very nice interpretation also faces a serious philosophical problem. Whether or not humans and animals are equal in moral status (e.g. Singer (2002), ch. 1), animals clearly have significant moral status. Consider the following from Robert Nozick (1974, 35-36):

Animals count for something. Some higher animals, at least, ought to be given some weight in people's deliberations about what to do. It's difficult to prove this. (It's also difficult to prove that people count for something!) We first shall adduce particular examples ... If you felt like snapping your fingers, perhaps to the beat of some music, and you knew that by some strange causal connection your snapping your fingers would cause 10,000 contented, unowned cows to die after great pain, or even painlessly and instantaneously, would it be perfectly all right to snap your fingers?

Surely the answer to Nozick's question is that it wouldn't be perfectly all right, and would even be very wicked. This would be true even if we added that you are very careful to distinguish humans and animals so that snapping your fingers will not brutalize you (Nozick (1974), 36), that no one else was going to make use of the unowned cows, etc. Given the way that animals do seem to matter morally, the idea that God might permit us to just do whatever we want to them seems unbelievable.

The nice interpretation is better. On this view, our authority is meant to be employed in service to those under us; it is first and foremost a responsibility as opposed to a privilege. It is, broadly speaking, the sort of authority possessed by leaders of legitimate governments, or of a trustee acting in place of someone who is incapacitated, or of parents over children. (More specifically, since our authority is delegated by God, it might be like that of an older sibling tasked with caring for the younger children.) Indeed, those with such responsibility are often expected to prioritize the interests of those in their care. Ours would be a public governance, in the sense that those over whom we hold authority (or others speaking on their behalf) would have legitimate complaints if we misused our power: we couldn't say our decisions were 'none of their business', that we didn't owe them a justification for our actions (cf. Anderson (2017), ch. 2). Since (besides the 'private' government posited by the other interpretation) this is basically the other kind of authority we're familiar with, positing that we have this sort of authority is the natural alternative for those who reject the not very nice view. I take it that Andrew Linzey $(2000,12,102)$ is endorsing a version of the nice interpretation when he writes: 
Far too often, Christians have accepted the common secular view that we are the masters of animals, their rulers or owners - utterly forgetting that the dominion promised to humanity is a deputized dominion, in which we are to stand before creation as God's viceregents, putting into effect not our own egotistical wants but God's own law of love and mercy ... . Dominion means responsibility - that we have a divine duty to care for the earth - but so often we have been silent when others (including Christians themselves) have taken it to mean that the world is ours and we can do as we like with it.

Defenders of the nice interpretation also often express it by saying we are stewards of the animals, charged with caring for them.

The requirements of public governance differ with context. Democratic citizens are generally assumed competent to decide how things should be run, so that legitimate governance comes about through their selecting leaders responsive to the popular will. This isn't true for small children, incapacitated individuals, etc. There, we must instead rely on our best judgements about what's good for those in our trust, or about what they would choose for themselves. There are speculative proposals for representing animals in democratic processes (e.g. Meijer (2019)), but animals obviously cannot participate in democracy in the way we can. Any governance would largely need to follow the latter model, then. (We'll return to issues of competence later.)

In general, the sort of authority involved in public governance extends only to those exercises of authority necessary to advance the aims for which our authority was granted; attempts to extend authority beyond these grounds are arbitrary and tyrannical. A sergeant can order you to charge the enemy, but not to vacuum his carpet, even if you'd rather do the latter. This is because his authority over you is justified by military necessity and doesn't extend beyond exercises necessary to further proportionate military aims. The same logic would seem to extend to the authority posited by the nice interpretation: insofar as it has been granted for the sake of the animals' interests, it would not justify our interfering with animals for other purposes. The nice interpretation is therefore compatible with thinking there is a default presumption in favour of letting animals be (again, see later).

The nice and not very nice interpretations are logical contraries but not logical contradictories: there are other logically consistent views which do not fall under either interpretation. As a referee notes, all that immediately follows from rejecting the claim that humans have no obligations to animals is that at least one human has at least one obligation to at least one animal. But I think many of the logically consistent alternatives can be easily rejected in context. Dominion in the text is pretty clearly a relation between humans in general and animals in general; if it involves obligations, this rules out the idea that these obtain only between some humans and some animals. Another consistent view is one on which humans have duties not to harm or interfere with animals, but no positive duties to benefit them or prevent their coming to harm (cf. the later subsections titled 'Relationships and positive duties' and Sovereignty'). But merely ordering humans to leave animals alone doesn't seem to involve giving them any sort of authority or dominion. While not logically exhaustive, I do think the two interpretations considered here basically capture the two things one might prima facie plausibly mean in saying that humans possess dominion over animals.

We can further distinguish between two different forms of the nice interpretation. The environmentalist interpretation views our responsibilities towards wild animals as directed towards aggregates of wild animals: we're expected to promote the good of species, or something like that, not of individual animals. This perspective governs actual 'wildlife management'. Holmes Rolston III writes that: 'Hundreds of elk starve in Yellowstone 
National Park each year, and the Park Service is not alarmed, but the starving of an equal number of grizzly bears, which would involve about the same suffering in psychological experience, would be of great concern' (Rolston (1985), 722).The claim is not that we have extra reason to care about grizzly bears starving because they're endangered; the claim is that we should care only for that reason. As Elizabeth Anderson notes, 'The environmentalist's object of concern is typically an aggregate or system: a species, an ecosystem, the biosphere. Organisms, from this perspective, are fungible, valued for their role in perpetuating the larger unit, but individually dispensable' (Anderson (2004), 278). We can distinguish the environmentalist interpretation from the individualist interpretation, which views our obligations as directed towards protecting the interests, rights, etc. of individual wild animals themselves. Of course, there is a spectrum of hybrid views on which we are supposed to care about both individuals and aggregates.

Someone who accepts the environmentalist interpretation (or a hybrid which places comparatively little weight on the interests of individual animals) might deny that we have obligations (or strong obligations) to implement proposals like those mentioned in the introduction. These were aimed at benefiting individual animals, not at maintaining biodiversity or anything like that. They might further claim that implementing these proposals would actually be wrong in cases where doing so would harm species, biodiversity, etc. For example, if genetically modifying tigers to be herbivorous would change them so radically that their offspring would not be members of the same species, and if the creation of this new species could not make up for our harming this old species, a proponent of this view might claim that engaging in such modification would be ruled out by the dominion command. So it's important for my purposes whether the environmentalist interpretation is correct.

One objection is that it risks proving too much. I doubt anyone was bothered by news of our having driven the New World screwworm from North America or by the suggestion that we drive it from South America as well. But destroying the screwworm involves eliminating a species for no corresponding species-level benefit: the screwworms cause all sorts of suffering to individual animals but (as far as I know) aren't any kind of serious threat to biodiversity. Robust versions of the environmentalist position therefore risk implying that it was wrong to drive the New World screwworm from North America, and it would be a further wrong to eliminate it entirely. But even people who don't think we are obligated to eliminate it to help animals generally don't think it would be wrong to do so.

Perhaps a deeper worry about the environmentalist interpretation is that it seems to be fundamentally confused about what matters. Tom Regan (2004, 361-363) derides positions which care only for species, ecosystems, etc. as 'environmental fascism'. Just as fascism is concerned only for the nation, not the individual, these collectivist views overlook the intrinsic value possessed by individual animals. It certainly seems true that individual animals matter a great deal on their own: why else is it so bad to painfully kill Nozick's ten thousand happy cows? But in light of this, it would be weird for God to issue a command which was sensitive only to the value of aggregates. And indeed, a number of passages in the Hebrew Bible and Jesus' teachings presuppose divine and human concern for individual animals, not merely aggregates (Bauckham (2011), ch. 4).

In light of this, I will assume that a plausible interpretation of the dominion command will assign substantial prima facie obligations to individual animals. This is itself enough for the conclusions I will later draw about interventions which do not seriously conflict with environmentalist values. But I will further assume that, in the case of serious conflict (as might exist in the case of re-engineering predators), individualist considerations generally win out. (I am not thereby saying such interventions are obligatory, or even permissible: perhaps they aren't for other reasons which I discuss in the next section. At this point, I'm merely saying they aren't ruled out by environmentalist worries.) I think this assumption 
will be more controversial. It's driven, for me, largely by a fundamental intuition that what really matters is the condition of individuals rather than aggregates, and that God would recognize this in issuing a command. For those who don't share this intuition, I can say a few further things. One is that removing (say) predatory tigers from ecosystems needn't mean the end of predatory tigers: we could keep some in special sanctuaries, say, and give them lab-grown meat. At the same time, we might introduce cool new herbivorous species into the ecosystem. Of course, the old tigers would no longer play their natural role in the ecosystem, but I don't really play my natural role in the ecosystem, either, and that seems fine. Another point is that our unreflective intuitive judgements are almost certainly biased in favour of environmentalist over individualist considerations here. One reason involves 'scope insensitivity': tremendous numbers of individual animals suffer from predation, and it's difficult to imagine that our intuitions are in any way sensitive to the immense difference between, say, millions so suffering and trillions so suffering (cf. Crummett (2017), 80). Another is 'status quo bias': our tendency to evaluate the status quo more positively, whatever it happens to be. Were we living in an Edenic paradise and considering whether to introduce predation, we would be much more horrified by it than we are now (cf. Jackson et al. (2021), 147-148; for further discussion, see McMahan (2016), sec. 4; Horta (2017), sec. 5; Jackson et al. (2021), ch. 10). I will not make any further assumptions (e.g. about whether a 'pure' individualist interpretation is correct or whether we also have some obligations concerning aggregates). How one answers these questions should not make any difference to how one evaluates the implications of the position which I draw out later.

All that being said, it could, in principle, turn out that the best way to discharge our obligations to individuals is by promoting the health of aggregates. We would be ultimately concerned with individuals, but practically speaking would focus on aggregates. This might be true if the flourishing of aggregates is the best proxy for the flourishing of individuals. But if the proposals mentioned in the introduction would really work, this isn't true: promoting the welfare of individuals might entail eliminating some aggregates, altering others, intervening to help individuals even when their well-being is irrelevant to the aggregate, etc. It could also be true if preserving aggregates and otherwise leaving animals to their own devices was somehow constitutive of their individual flourishing. We'll return to that in the next section.

I'll assume that God has successfully given us the relevant authority: that is, in decreeing that we have the relevant rights and responsibilities, God has brought it about that we actually have them. This is just part of the theological picture in question. It doesn't require accepting divine command theory or some other form of theological voluntarism, just as thinking that the state can assign special rights and responsibilities to a police officer, or a parent to an older child, doesn't require accepting stately or parental voluntarism. Presumably God had reasons for giving us this authority; presumably they involved the value of animals and the fact that it would be better if we cared for them. We might wonder why God would give us this job, as opposed to ending the animal suffering himself. Perhaps the answer involved the value of creaturely responsibility, or something like that. This implicates larger questions about the problem of evil. I won't dwell on the issue, since, again, I take God's having given us the job to be part of the relevant picture, whatever God's reasons were.

The claim that God has given the relevant authority need not rest on any particularly chauvinistic claims about humanity. Parfit $(2011,31)$ notes that 'We are the animals that can both understand and respond to reasons. These abilities have given us great knowledge, and power to control the future of life on Earth.' In light of this, if God's going to give any earthly creatures the relevant authority, God will give it to us; only we can exercise it. Admittedly, it's not clear how we were originally supposed to exercise the 
authority. Our power over the environment was fairly minimal until recently. Perhaps we were meant to have 'preternatural powers' of the sort posited by Peter van Inwagen (2006) but lost these when we fell. Perhaps we were supposed to cooperate with angels, but the relevant angels fell. Perhaps the natural order was just supposed to work really differently. Perhaps the intention was always for us to only develop the power needed to fully exercise the authority very late in the day; perhaps (we flatter ourselves) we have the wisdom to exercise it responsibly in a way that our ancestors would not have. Who knows? What matters practically is that technological development may allow us to exercise it now and, to a greater extent, in the foreseeable future.

If all this is right, we have a collective duty to look after the wild animals. There's a question about how to discharge the duty. Who is actually supposed to do this - me? you? everyone at once? An analogous problem is faced when 'the international community' has an obligation to provide humanitarian assistance after a catastrophe, or prevent one nation from engaging in offensive warfare against another, or protect a minority group from genocide at the hands of their government. Who is actually supposed to prevent the genocide - should I buy a gun and hop on a plane? Kok-Chor Tan (2006, 102-106) argues that the best solution is to 'institutionalize' the duty. We can create a governing body with the authority to assign responsibilities to various actors in a coordinated and fair way. The obligation of most individual people will just be to support the work of this body in appropriate ways - by paying taxes, by voting for politicians who play their part in making the body function properly, etc. Something like this is probably what's needed for us to fully discharge our obligations to wild animals (Johanssen (2021), 30-32), though I won't design such an institution here. Without such an institution, individual people or organizations might do what they reasonably can to alleviate animal suffering (e.g. doing relevant research, donating to the Wild Animal Initiative, advocating for the creation of a relevant institution, etc.).

\section{Alleviating wild animal suffering}

At least given the interpretation of the dominion command suggested above, it seems clear enough that we at least have a prima facie obligation to reduce wild animal suffering: if, to take a slight variant on Nozick's case, we could prevent the torturous deaths of 10,000 unowned cows by snapping our fingers, it seems clear that we'd be obligated to do so. But, as noted, some philosophers deny that we have a collective obligation to implement the more realistic interventions mentioned in the introduction, or at least to implement the more drastic ones. Mostly this is because they think we don't stand in the right relations to wild animals for these sorts of interventions to be obligatory (or permissible). Here I argue that, if the previous account of dominion is true, we do stand in the right relations and these arguments are undermined.

\section{Relationships and positive duties}

Negative duties are duties not to do something (e.g. not to hurt you); positive duties are duties to do something (e.g. to help you). Clare Palmer (2010, esp. ch. 5) suggests that positive duties (at least generally) arise because of special relationships that obtain between ourselves and those to whom we're obligated. We have particularly strong positive obligations to our friends, our family, members of our community, etc. Even with distant strangers, we stand - in the modern, globalized world, at least - as co-members of a single human community linked by 'mutually recognized communication, the ability of humans to justify themselves to others, reciprocity in economic relations, mutual cooperation, the joint organization of political and other institutions, membership of political 
communities, the sense of a political "world order,"' etc. (ibid., 121). However, we wouldn't stand in any such relationships with, say, starving individuals on Venus (or 'a hitherto undiscovered island'; ibid., 86) with whom we'd never interacted. Accordingly, we wouldn't be obligated to feed needy Venusians - or, if we were, such duties would be 'very much weaker than duties to assist comparably hungry humans on Earth', even as it would be 'seriously wrong to land on Venus in order to torture and eat the suffering Venusians or to destroy the few crops they have left' (ibid., 87).

On this view, we might have strong obligations to domestic animals: we stand in various relations to them, and are often responsible for the fact that they can't provide for themselves. Insofar as we've violated our negative duties towards wild animals (by destroying their habitats, etc.), we may well have positive duties of reparation to make up for the harm we've caused. But we won't in general have obligations to aid wild animals - say, by vaccinating them. It's not our fault that they face disease, and we do not stand in the special relations necessary for us to have positive duties (or strong positive duties) towards them. We'd be permitted to aid wild animals, but not obligated to do so, even if it would greatly benefit the animals. ${ }^{1}$

One advantage of Palmer's view is supposed to be that it accounts for the 'laissez-faire intuition', 'roughly, the idea that, while we have obligations to assist and care for domesticated animals, we have no such obligations toward animals in the wild' (Palmer (2010), 63). Another is that the idea that positive obligations depend on special relationships is supposed to be independently plausible. For my part, I find the view independently implausible. Our positive duties surely can be strengthened by special relations. But I think our positive duties to aid the Venusians, as well as various human beings who may be excluded by Palmer's account (see Johanssen (2021), 34), are still quite strong.

However, the dominion view provides an additional way of resisting Palmer's conclusion - one consistent with her view of the grounds of positive duties. On the dominion view, we do stand in a morally significant special relationship with wild animals: we're their divinely appointed caretakers. If the indirect relationships I stand in with distant strangers can generate positive duties, surely this can, too.

Cost

John Hadley thinks we have some duties to aid wild animals. He claims we have 'a duty to provide aid at minimal cost to ourselves ... to free-roaming nonhuman animals ... in dire need' (Hadley (2006), 446). He thinks of this as applying in the case of 'ecological catastrophes', such as drought-induced famines. But he denies that we have a duty to eliminate predation - or, at the very least, he denies that the grounds he provides for thinking we have a duty to aid animals in dire need entail that we have a duty to eliminate predation. There are three reasons for this (ibid., 449-450), two of which would also apply to suggestions that we eliminate ordinary diseases among wild animals, etc. The one which applies only to predation appeals specifically to the interests of predators. Hadley suggests thinking of our obligations to wild animals as 'essentially no different to those we have to severely cognitively impaired distant strangers' (ibid., 446). In that case, we need to think of predation as analogous to a situation where 'the harm caused by distant strangers to each other would be in the service of meeting their most basic needs for sustenance', and 'in a world where cannibalism between the cognitively impaired was prevalent, out of necessity in order to survive, then it is not at all clear that morality would demand intervention to prevent it' (ibid., 449-450). Whatever we think of this, the point of the predation-related measures mentioned in the introduction is not to starve predators to death, but to bring about a world where no individual needs to engage in the analogue of such cannibalism to meet their basic needs for sustenance. 
Hadley's second point is that rescuing prey animals in dire need could not be done at minimal cost to ourselves. He writes (ibid., 450) that:

when an animal is in the jaws or claws of a predator it is beyond being helped in any relatively inexpensive way. It is likely that an individual rescued from such a predicament would require evacuation, major surgery, and extensive rehabilitation, to say nothing of the expense involved in meeting the needs for sustenance of the predator(s) concerned.

A similar point could be made about, for instance, animals suffering from serious diseases. We could permissibly bear the cost, but wouldn't be obligated to.

of course, the proposals under discussion don't involve medevacking injured prey animals. (How would we find them?) They're preventative measures, aimed at, for example, keeping animals from getting sick or getting attacked by predators to begin with. The cost-benefit ratio of these proposals, if they're successful, would certainly be better than the medevac option: the amount of evil prevented by permanently re-engineering nature to reduce suffering is literally unimaginable, and it's hard to believe that the cost-per-life-saved would be anything like that involved in the medevac option. Still, there's a question about whether we'd be obligated to bear the cost in absolute terms. My own sense is that, in light of the immense stakes, we would, even if the costs to us were more than minimal. ${ }^{2}$ But the dominion view provides an additional consideration. Even if we need only bear minimal costs to aid distant strangers, surely we can be obligated to bear more than minimal costs to aid those with whom we stand in special relationships. And as mentioned, on the dominion view, we stand in morally significant relationships with wild animals.

\section{Rescue vs development aid}

Hadley also makes a third point, one which bears on the issue of preventative measures. He says that:

even if such [preventative] measures were effective at stopping predation, intervention at that time would not constitute the provision of disaster relief; instead, spending resources on individuals when they are not in dire need but are for the most part healthy and content, is more akin to the provision of development aid. Whether we have an obligation to provide aid other than disaster relief to nonhuman animals, or indeed cognitively impaired distant strangers, is not the issue here. (Hadley (2006), 450)

As the final sentence suggests, Hadley's main goal is showing that his account doesn't immediately entail that we have an obligation to end predation. He doesn't offer an account of why the obligation to provide development aid might be less pressing than the obligation to provide disaster relief, but since this seems to mesh with common-sense intuitions, we can leave it aside.

One problem is that 'dire need' may be the rule rather than the exception in nature. Again, most wild animals die quickly after being born. We might instead think of wild animal communities as in something like a permanent state of disaster (cf. Johanssen (2021), 41). Another worry concerns the strength of our obligations to provide development relief. The reader won't be surprised to hear that my own intuitions are that the obligation is quite strong here, strong enough to be obligatory given the likely cost-benefit ratio. 
However, the dominion view again raises another consideration. If some distant land suffers a high infant mortality rate, perhaps you think our obligation to alleviate this by building new hospitals is weak. However, if one of our own provinces suffers a high infant mortality rate, it hardly seems credible for the government to demur on the grounds that building hospitals would be development aid rather than disaster relief. Yet there's an obvious respect in which the latter is more like our situation, on the dominion view: we are governors of the animals. I think this makes the development assistance move less promising.

\section{Sovereignty}

Suppose they do things differently in another country. Our way is actually better. We're powerful enough that we could impose our way of doing things on them without unacceptable costs. And we know all this. We might still think that it would be wrong for us to impose our way on them. We often think that communities should tend to their own affairs, and let other communities do the same, except in fairly extreme cases. How they do things is their business, not ours. Similar points might be made about your neighbours, who raise their children in a way inferior to your own, and so on.

Some authors claim that the same is true of wild animal communities. Obviously, wild animals are not organized into the modern nation states which we ordinarily think of as possessing political sovereignty. But neither are, say, many modern indigenous communities or historical stateless societies (Donaldson and Kymlicka (2011), 171-174). Neither is my neighbors' family. Yet these communities possess a right of non-interference. Regan (2004, 357) writes:

If . . . we are told that respecting the rights of animals in the wild ... does not guarantee that we will minimize the total amount of suffering wild animals will suffer over time, our reply should be that this cannot be the overarching goal of wildlife management, once we take the rights of animals seriously ... Being neither the accountants nor managers of felicity in nature, wildlife managers should be principally concerned with letting animals be, keeping human predators out of their affairs, allowing these 'other nations' to carve out their own destiny.

Martha Nussbaum $(2006,373)$ suggests that:

It seems at least coherent to say that the human community has the obligation to refrain from certain egregious harms toward animals, but that it is not obliged to support the welfare of all animals . . . Fulfilling our negative duties would not be enough to ensure that all animals have a chance to pursue flourishing in their own way, but it might be that nothing more is morally required of us: the species themselves have the rest of the task of ensuring their own flourishing. We might further defend such a conclusion on the grounds that . . . the very idea of a benevolent despotism of humans over animals, supplying their needs, is morally repugnant: the sovereignty of species, like the sovereignty of nations, has moral weight. Part of what it is to flourish, for a creature, is to settle certain very important matters on its own, without human intervention, even of a benevolent sort.

And Sue Donaldson and Will Kymlicka (2011, 170-171) write:

it may help to contrast our [sovereignty-based] model with a 'stewardship' model, found in some environmentalist literature (and in some public policy). In this 
model, habitat is set aside for wild animals in the form of wildlife sanctuaries, refuges, or a national park system. These wild areas are under the management or stewardship of humans, for the shared benefit of both humans and animals . . . On a sovereignty model, by contrast, recognizing another community's sovereign territory involves recognizing that we have no right to govern that territory, let alone to make unilateral decisions by stewards on behalf of wards ... Sovereign peoples have the right to make their own decisions about the nature of their communal life, providing these do not infringe on the rights of other sovereign nations. This includes the right to make mistakes, and to follow paths that outsiders might see as misguided.

All of these authors agree that some interventions might be justified: for example, to help animals survive some natural catastrophe, or to repair damage done by humans. (Nussbaum writes, of the passage quoted, that 'There is much truth in this imagined argument' but that it 'cannot be accepted in full' $(2006,373)$.) But all agree that radical interventions such as ending predation would wrongfully violate animal sovereignty.

One worry is that appeals to sovereignty apparently rely on the background belief that animals can get along on their own, without our intervention. If they can't, our 'benevolent despotism' would seem more benevolent than despotic. Regan (2004, xxxvii) explicitly states that 'our ruling obligation with regard to wild animals is to let them be, an obligation grounded in a recognition of their general competence to get on with the business of living, a competence that we find among members of both predator and prey species'. Nussbaum's suggestion requires that 'the species themselves have the rest of the task of ensuring their own flourishing', which hardly makes sense if they can't do so. And Donaldson and Kymlicka (2011, 175-176) write:

If wild animals are to be accorded sovereignty, we need to show that they are competent to take care of themselves ... . What sort of competence is needed for sovereignty? We would argue that for wild animals - as indeed for humans - what matters for sovereignty is the ability to respond to the challenges that a community faces, and to provide a social context in which its individual members can grow and flourish. And in this sense, it seems clear that wild animals are competent ... wild animals, both individually and collectively, confront the challenges of life in the wild, successfully tending to their needs and minimizing risks.

But it's far from clear that animals do quite well on their own. Again, most quickly die; others are subject to ill-health, predation, starvation, etc.

Donaldson and Kymlicka acknowledge this somewhat: they note that a human community whose members were subject to predation and starvation to the extent that wild animals are would be viewed 'as a "failed state," or in any event one that requires some degree of external intervention' (Donaldson \& Kymlicka (2011), 175). They respond that:

in the context of ecosystems, food cycles and predator-prey relationships are not indicators of 'failure.' Rather, they are defining features of the context within which wild animal communities exist; they frame the challenges to which wild animals must respond both individually and collectively, and the evidence suggests that they respond competently.

It's true that these don't indicate 'failures' in the sense that (for example) these communities should have done something other than what they've done. But it's nonetheless true 
that they lack the capacity to protect their members. And by altering these ecosystems, we can make the challenges to which these communities must respond more manageable.

Donaldson and Kymlicka also grant (ibid., 175-176) that individual r-strategists, with their high death rates, don't seem 'competent', so that 'the argument is weaker' for these animals. We might add that even animals who respond 'competently' often bear serious costs. For example, predation imposes not only the risk of being eaten, but also difficulty finding food (because animals must spend time hiding), along with chronic stress and other psychological harms. Animals in ecosystems without predators exhibit island tameness'; they are friendlier and less stressed (Johanssen (2021), 39). Donaldson and Kymlicka nonetheless maintain that we must 'respect the sovereignty of wild animals, including those for whom there is minimal evidence of competent agency' (Donaldson \& Kymlicka (2011), 176). This is partly due to worries about our fallibility; again, I'm just assuming in this article that the interventionist proposals will work properly. The other is that 'if we are to respect wild animals as members of their own kinds of communities, autonomous and self-regulating, then interference in the defining features of their form of community would mean an end to their independence' (ibid., 176).

If the significant majority of affected animals would significantly benefit from intervention, I think the claim has to be that there is some deontological prohibition against violating the 'independence' of wild animal communities in order to help (most of) their members. I think this is implausible: I more or less think the failed state analogy holds. But dominion again provides a further consideration. God's sovereignty outweighs the sovereignty of human nations, and presumably outweighs the sovereignty of wild animal communities, too. So if God tasked us with ensuring the welfare of wild animals and delegated to us the authority needed to do so, we will have the right, and obligation, to intervene in their communities for that purpose after all. Of course, this wouldn't license just any intervention. I mentioned before that the nice interpretation licenses interventions only for the specific purposes posited. So this is compatible with accepting wild animal sovereignty and respecting it as the default.

\section{The non-identity problem}

Christine Korsgaard (2018, ch. 11) also argues that it would be wrong for us to eliminate predation and otherwise radically re-engineer animals. The essence of Korsgaard's critique rests on a version of the non-identity problem: the idea is that, while the animals who existed at the end of our process of reengineering might be better-off than the animals who would exist had we not intervened, these would be different animals, and this is morally significant. One way to frame the issue is to say that introducing extreme genetic modifications to already existing animals would not be identity-preserving. If we captured all the predators and turned them into herbivores, and captured all the herbivores and reduced their rate of reproduction, and added in some added resistance against temperature, disease, etc. as a bonus, the resulting individuals wouldn't be the individuals we started with: we would have destroyed those individuals and replaced them with new ones. Korsgaard $(2018,187)$ writes that:

Changing a creature's species is not doing him any good, but rather killing him in order to make something else with his organic parts. To see why this matters, forget the future for a moment, and suppose we are just talking about an existing generation of animals ... Suppose that we discovered that rabbits have more resistance to disease than foxes. Could we do the foxes any good by turning them into rabbits? How would that be any different from killing all the foxes and replacing them with rabbits? 
Killing all the animals to replace them with happier ones seems ethically problematic, at least within Korsgaard's Kantian framework, which commands us to treat animals as ends in themselves, never as mere means (2018, ch. 8).

But I think the argument, on this understanding, doesn't work. First, if we accept a psychological rather than a bodily criterion of identity, as Korsgaard herself sometimes seems to (cf. Paez, 2019, 288-290), it seems unclear that the relevant changes couldn't be identity-preserving. But second, the point of gene drives is not to modify animals one by one, but to introduce heritable changes that spread throughout a population on their own. By introducing germline modifications to gametes, ${ }^{3}$ we could bring it about that new individuals are created who will have the relevant modifications and pass them on to their offspring but without introducing identity-destroying modifications to any currently existing, morally significant animals (Paez (2019), 287).

So the question instead needs to be about future generations of animals. It does seem plausible to think that efforts to reduce suffering among future generations of wild animals would also change the identity of the individual wild animals in those generations. In that case, engineering a future paradise might not be better for any of the individuals who otherwise would have existed, since they don't exist in the paradise world. And given Korsgaard's 'tethered' view of goodness, on which all goodness is ultimately goodness for someone, we can only say one outcome is better than another if it Pareto dominates another (Korsgaard (2018), 157-158). So the paradise world is not better, simpliciter, either (ibid., 183-184).

Inferring from this that we have no obligation to engineer paradise risks well-known problematic implications. If we emit lots of carbon, life might be worse for future people, but they will be different people. Can we therefore produce as much carbon as we want? Korsgaard answers that we essentially stand in a special creator-creature relationship with future people, and that this gives us an obligation to improve the lives of " "the members of future generations" ... whoever they turn out to be' (ibid., 185). However, we do not stand in any such relation to future wild animals, and therefore have no obligation to ensure that future wild animals, whoever they may be, are as well-off as possible (ibid., ch. 11.4). We would take such a relationship on, with its attendant obligations, if we began re-engineering animal species to fit our own designs (ibid., 185-186). But we have no obligation to take it on.

Korsgaard further argues that it would be wrong to take this relationship on. Individual animals have a stake in the continued flourishing of their communities. But we undermine this if we intervene in nature to re-engineer predators. She (ibid., 208-209) writes:

Communities of lions and leopards and sharks are also normatively significant groups, to whom we have obligations, including obligations to support or at least not to undermine the continuing existence of their communities. We should preserve these communities for the sake of the individual animals in them. Now it becomes important that we have an obligation to improve things for the animals of the future' by putting an end to predation only if we take on the role of the creator with regard to them, and that we have no obligation to do that . . . But we do have obligations to support or at least not to undermine existing animal communities even if we don't take on the role of the creator. Arguably, we would violate those obligations by taking on the role of creator with respect to the world's future animals, if this leads us to do things to undermine existing animal communities. To that extent ... I think the charge that this would be 'playing God' in a bad sense is justified. It seems to me that we would be undermining existing animal communities, especially those of the predators, if we started genetically manipulating the predators or phasing them out of existence. 
One worry for Korsgaard's approach concerns the fact that her claim that we have no obligation to improve things for future animals requires a very controversial solution to the non-identity problem (cf. Roberts (2019)). Another concerns the fact that many future animals - many more if we refuse to intervene - will have net negative lives. Mightn't we be obligated to prevent their suffering, even if it means their non-existence (cf. Paez (2019), 287)? But the dominion view again introduces another line of criticism. Korsgaard is explicit that God would stand in the relevant creator relation and therefore have the relevant obligations to his creatures. (She therefore rejects the 'non-identity theodicy' (Vitale (2020).) She writes:

if you are going to create conscious, sentient creatures, you have a duty to make conditions as good as you possibly can for them. That is a duty you owe to your creatures, in your capacity as their creator, and in their capacity as your creatures, whoever they might turn out to be ... If nature itself had an omnipotent creator, creating the world from scratch, that creator would have been free to design his creatures however he liked, and as far as we can see, that creator could have designed creatures who do not have to live at each other's expense. (Korsgaard (2018), 185-186)

But on the dominion view, God himself has delegated to us these responsibilities. We are, as Linzey says, 'God's viceregents', tasked with implementing 'God's own law of love and mercy'. In some sense, we are supposed to be 'playing God': the elder sibling tasked with watching the younger kids is not their creator, but has (at least some of) the rights and responsibilities of their creators while acting in loco parentis. So on the dominion view, our obligations towards the animal are a question in creation ethics after all.

Korsgaard doesn't explicitly say whether we could intervene if we did have obligations to improve things for future animals. All that immediately follows is that we'd have conflicting duties. But it seems plausible that we could intervene. Suppose the distinctive way of life of some human community caused as much death and suffering to members of other human communities as predation causes to prey. Suppose that the members of this community were somehow not blameworthy for this, but also for some reason unable to change their ways on their own. Suppose we could intervene to slowly alter their way of life over several generations, destroying what is distinctive about the community but also freeing future members of other communities from the harms they cause, and without causing any other harms to the members of the target community. I think we could do this. But that seems analogous to the situation with predators, assuming we have obligations to future animals just as we have obligations to future humans.

\section{Conclusion}

People claiming divinely granted authority to govern others have a bad track record. Perhaps it will remind anti-interventionists of, say, the claims of men to have divinely given authority over women, or the claim of Pope Nicholas V, in Dum Diversas, to authorize the Portuguese crown's conquest and subjugation of the non-Christian peoples of the world. But I've attempted to show that these alleged parallels don't hold up. I think the account of dominion presented earlier coheres with what a good God might do. And there are independent objections to the anti-interventionist arguments. If things were otherwise - if, say, intervention seemed very obviously wrong, without a religious belief in human dominion - that might be a powerful reason to doubt that God had really given humans the relevant kind of dominion, just as, for example, the otherwise obvious wrongness of genocide is often taken as reason to doubt that God really commanded the 
genocides recorded in the Bible. The dominion-based argument and other objections to anti-interventionist arguments are therefore mutually reinforcing: the dominion argument provides an additional route to the conclusion; the other arguments help show that the conclusion is not so implausible that we should instead reject the claim about dominion.

It could be still be claimed that, in practice, the idea of dominion is too dangerous to be useful: humans being what we are, we'll use it to justify mistreating animals. My view is that, humans being what we are, those who wish to mistreat animals will find some justification for it, whatever I say. I'm more worried that genuinely well-intentioned friends of animals, influenced by arguments like those in earlier sections and by prevailing conservationist sentiments, will claim that we should avoid intervention in favour of 'letting animals be'. (It's easier for anti-interventionist arguments to gain social traction anyway, given that 'letting animals be' doesn't require that we bear the costs of intervention and that many people find intervention intuitively bizarre or repugnant.) If this delays the implementation of suffering-reduced proposals even by, say, just one month, the amount of suffering unnecessarily allowed might be immense. If, as seems quite possible, it delays these proposals indefinitely, the cost could be catastrophic.

Still, there are many questions I haven't addressed. For example, I have stipulated away, rather than seriously discussing, the enormous question of our fallibility (but see Johanssen (2021), ch. 4). And there are other questions about the implications of dominion for this and other issues which I haven't even brought up. These are questions for future research.

\section{Notes}

1. In my view, saying the obligations are just very much weaker is substantially more plausible: it allows us to say that we'd be obligated to snap our fingers to feed the Venusians or Nozick's cows while denying we'd be ultima facie obligated in realistic cases where aiding is more difficult. But nothing I'll say turns on this.

2. Someone could claim that the immense stakes don't matter because preventing human suffering is lexically prior to preventing animal suffering (i.e. we should prioritize preventing any amount of human suffering over any amount of animal suffering). This should not appeal to anyone who accepts the nice interpretation, since it would render God's command to care for the animals pointless: any attempt to help animals comes with some opportunity cost in terms of preventing (at least expected) human suffering. Anyway, the lexical priority claim doesn't seem right: if I can prevent a human hangnail or the agonizing death of Nozick's 10,000 happy, unowned cows, I should prevent the former. More intuitively plausible would be the claim that sufficiently bad human suffering merits lexical priority. But it's extremely difficult to grant lexical priority to sufficiently bad human evils but not to trivial human evils for reasons explored in Crummett $(2017,80-83)$ and Case (2020). Assigning lexical priority of any sort will also generate problems in probabilistic cases (which all real cases are). If the claim is that we should assign lexical priority only in cases where we are certain that we can prevent a human horror, the claim is irrelevant, since we are never certain of that. If the claim is that we should assign lexical priority to reducing the chance of a human horror by any amount, the dominion command again becomes irrelevant: there is probably always something I could do instead of helping animals which would have some tiny chance of preventing a human horror. And anyway, it seems implausible to think that, for example, reducing the chance of a human horror by 1 in $10^{\wedge} 10^{\wedge} 10^{\wedge} 10^{\wedge} 10$ should take priority over the near certainty of saving Nozick's cows. If the claim is instead that I should assign lexical priority to decreasing the chance of a human horror by a sufficiently large amount, implausible results are generated in certain cases where I must make multiple decisions, for reasons explained in Huemer (2010).

3. Or to early embryos, if they don't yet have moral status (as Korsgaard (2018), ch. 5.3) appears to think).

\section{References}

Anderson E (2004) Animal rights and the values of non-human life. In Sunstein C and Nussbaum M (eds), Animal Rights: Current Debates and New Directions. Oxford: Oxford University Press, pp. 277-298. 
Anderson E (2017) Private Government: How Employers Rule Our Lives (and Why We Don't Talk About It). Princeton, NJ: Princeton University Press.

Bauckham R (2011) Living With Other Creatures. Waco, TX: Baylor University Press.

Case S (2020) Small evils and live options. Philosophia Christi 22, 307-321.

Clough D (2012) On Animals, I. New York: T\&T Clark.

Crummett D (2017) The problem of evil and the suffering of creeping things. International Journal for Philosophy of Religion 82, 71-88.

Dawkins R (1995) River Out of Eden: A Darwinian View of Life. New York: Basic Books.

Donaldson S and Kymlicka W (2011) Zoopolis: A Political Theory of Animal Rights. Oxford: Oxford University Press.

Esvelt K (2019) When are we obligated to edit wild creatures? Leapsmag. https://leaps.org/when-are-weobligated-to-edit-wild-creatures/ (accessed 23 February 2021).

Hadley J (2006) The duty to aid non-human animals in dire need. Journal of Applied Ethics 23, 445-451.

Hare J (2010) Animal sacrifices. In Bergmann M, Murray MJ and Rea M (eds), Divine Evil? The Moral Character of the God of Abraham. Oxford: Oxford University Press, pp. 121-137.

Horta O (2017) Animal suffering in nature: the case for intervention. Environmental Ethics 39, 261-279.

Huemer M (2010) Lexical priority and the problem of risk. Pacific Philosophical Quarterly 91, 332-351.

Jackson E, Goldschmidt T, Crummett D and Chan R (2021) Applied Ethics: An Impartial Introduction. Indianapolis, IN: Hackett.

Johanssen K (2021) Wild Animal Ethics: The Moral and Political Problem of Wild Animal Suffering. New York: Routledge. Korsgaard C (2018) Fellow Creatures: Our Obligations to the Other Animals. Oxford: Oxford University Press.

Linzey A (2000) Animal Gospel. Louisville, KY: Westminster John Knox Press.

McMahan J (2016) The moral problem of predation. In Chignell A, Cuneo T and Haltemann MC (eds), Philosophy Comes to Dinner: Arguments About the Ethics of Eating. New York: Routledge, pp. 268-295.

Meijer E (2019) When Animals Speak: Towards an Interspecies Democracy. New York: New York University Press.

Nozick R (1974) Anarchy, State, and Utopia. New York: Basic Books.

Nussbaum M (2006) Frontiers of Justice. Cambridge, MA: Harvard University Press.

Paez E (2019) A Kantian ethics of paradise engineering. Analysis 80, 283-293.

Palmer C (2010) Animal Ethics in Context. New York: Columbia University Press.

Parfit D (2011) On What Matters, I. Oxford: Oxford University Press.

Pearce D (1995) The Hedonistic Imperative. https://www.hedweb.com/hedethic/tabconhi.htm (accessed 23 February 2019).

Regan T (2004) The Case for Animal Rights. Los Angeles: University of California Press.

Roberts MA (2019) The non-identity problem. Stanford Encyclopedia of Philosophy. https://plato.stanford.edu/ entries/nonidentity-problem/ (9 March 2021).

Rolston H III (1985) Duties to endangered species. Bioscience 35, 718-726.

Singer P (2002) Animal Liberation. New York: Harper Collins.

Tan K-C (2006) The duty to protect. In Nardin T and Williams MS (eds). Humanitarian Intervention. New York: New York University Press, pp. 84-116.

van Inwagen P (2006) The Problem of Evil. Oxford: Oxford University Press.

Vitale VR (2020) Non-Identity Theodicy: A Grace-Based Response to the Problem of Evil. Oxford: Oxford University Press.

Cite this article: Crummett D (2022). Human dominion and wild animal suffering. Religious Studies 58, 814-830.

https://doi.org/10.1017/S0034412521000354 